\title{
The Fate of $7\left[{ }^{14} \mathrm{C}\right]$-Methylguanine after Administration to the Rat
}

\author{
By VALDA M. CRADDOCK, A. R. MATTOCKS AND P. N. MAGEE* \\ Toxicology Research Unit, Medical Research Council Laboratories, Carshalton, Surrey
}

(Received 13 March 1968)

\begin{abstract}
1. To assess the significance of the methylation of nucleic acids known to be caused by certain carcinogens, the metabolic fate of $7\left[{ }^{14} \mathrm{C}\right]$-methylguanine was studied, with special reference to its possible incorporation into RNA and DNA. 2. The major part (approx. 95\%) of the dose was excreted unchanged in the urine. A small amount of $N$-demethylation took place, as evidenced by the formation of radioactive adenine and guanine, and expiration of ${ }^{14} \mathrm{C}$-labelled carbon dioxide. No evidence was obtained for the direct incorporation of 7-methylguanine into systems synthesizing nucleic acids, i.e. RNA in liver, DNA in intestine or in the foetus.
\end{abstract}

After administration of the carcinogen dimethylnitrosamine to the intact animal, 7-methylguanine is formed in the nucleic acids of liver, kidney and certain other tissues (Magee \& Farber, 1962). There are two ways in which the nucleic acids could become methylated. In the first, the preformed polymer could be methylated directly by dimethylnitrosamine or by one of its metabolites, and in this case an abnormally methylated nucleic acid might well be formed. The second possibility is the incorporation of 7-methylguanine during biosynthesis of the nucleic acid. The methylated base might derive from the methylation of a lowmolecular-weight compound by dimethylnitrosamine, or it may originate in the nucleic acid of another tissue. For example, liver nucleic acid may be directly methylated, and on necrosis of the liver cells the base may be liberated and become reincorporated into kidney nucleic acids. As 7 . methylguanine is a normal component of mammalian liver RNA (Dunn, 1963) and occurs in normal human urine (Krüger \& Salomon, 1898a,b), this latter reaction need not necessarily represent an abnormal process. Therefore, to assess the significance of methylation of nucleic acids in carcinogenesis, it was decided to investigate whether 7-methylguanine could be incorporated into nucleic acids during their biosynthesis.

Though it is known that the RNA (Mandel \& Borek, 1963) and DNA (Gold, Hurwitz \& Anders, 1963) of Escherichia coli become methylated after the synthesis of the polymer, by the action of nucleic acid methylase enzymes, it was not known whether this was the sole source of the methylated bases found in nucleic acids in mammalian systems,

* Present address: Courtauld Institute of Biochemistry, The Middlesex Hospital Medical School, London, W. 1. or whether 7-methylguanine could become incorporated during their biosynthesis. Certain methylated bases have been shown to be incorporated into nucleic acids (Novogrodsky, Gefter, Maitra, Gold \& Hurwitz, 1966; Remy, 1967). Therefore the possibility of incorporation of 7-methylguanine into RNA and DNA was investigated. A preliminary report of this work has been given (Craddock, Magee \& Mattocks, 1968a).

\section{MATERIALS AND METHODS}

Materials. $\left[{ }^{14} \mathrm{C}\right]$ Methyl iodide was purchased from The Radiochemical Centre (Amersham, Bucks.), guanosine from Koch-Light Laboratories Ltd. (Colnbrook, Bucks.) and $N N$-dimethylacetamide from British Drug Houses Ltd. (Poole, Dorset).

7-Methylguanosine was prepared by the method of Jones \& Robins (1963) with dimethyl sulphate, and was hydrolysed to 7-methylguanine with hot water.

Preparation of $7\left[{ }^{14} \mathrm{C}\right]$-methylguanine. A modification of the method of Jones \& Robins (1963) was used. [ $\left.{ }^{14} \mathrm{C}\right]$ Methyl iodide (1 mc, $4.7 \mathrm{mg}$.) was transferred in vacuo to a tube containing guanosine $(9 \cdot 8 \mathrm{mg}$.) dissolved in $N N$-dimethylacetamide $\left(0.7 \mathrm{ml}\right.$.) and frozen in liquid $\mathrm{N}_{2}$. Air was admitted to the tube, which was immediately stoppered and warmed to room temperature, and the contents were shaken before momentary release of the pressure. The tube was kept at room temperature for $16 \mathrm{hr}$. and then at $30-33^{\circ}$ for $26 \mathrm{hr}$., with occasional shaking. The solvent and unchanged methyl iodide were removed by use of a highvacuum line, first at room temperature and then at $40-50^{\circ}$, during about $1.5 \mathrm{hr}$. The residue was dissolved in water $\left(0 \cdot 2 \mathrm{ml}\right.$.), acetone $\left(2 \mathrm{ml}\right.$.) and a few drops of aq. $\mathrm{NH}_{3}$ soln. were added, followed by more acetone (about $5 \mathrm{ml}$.), and the solid was collected (by centrifugation), washed twice with acetone and dried in vacuo. The yield was $8.3 \mathrm{mg}$. of crude $7\left[{ }^{14} \mathrm{C}\right]$-methylguanosine. This product was dissolved in $1 \mathrm{~N}-\mathrm{HCl}\left(4-5 \mathrm{ml}\right.$.), hydrolysed at $100^{\circ}$ for $1 \mathrm{hr}$. and analysed on a Dowex $50\left(\mathrm{X} 12 ; \mathrm{H}^{+}\right.$form $)$column $(0.5 \mathrm{~cm}, \times 10 \mathrm{~cm}$. 
with a 1-3N-HCl exponential gradient; the flow rate was $25 \mathrm{ml}$. $/ \mathrm{hr}$., $10 \mathrm{ml}$. fractions being collected. The $E_{260}$ value of every fourth fraction was determined, and radioactivity of every second fraction was determined on $0.1 \mathrm{ml}$. of effluent with dioxan scintillator solution. The major radioactive peak was pooled and evaporated to dryness. To convert the residue into the basic form it was taken up in 1-2 ml. of water, made alkaline with a few drops of aq. $\mathrm{NH}_{3}$ soln., cooled in ice and centrifuged, and the solid was washed with ethanol (two lots of $0.5 \mathrm{ml}$.) and dried under reduced pressure. The yield was $2.0 \mathrm{mg}$., of specific radioactivity $153 \cdot 6 \mu \mathrm{c} / \mathrm{mg}$. (first crop), of $7\left[{ }^{14} \mathrm{C}\right]$-methylguanine. The combined liquor and washings were evaporated to dryness, the residue was dissolved in $0.3 \mathrm{ml}$. of water, ethanol was added, and the solid was collected, washed and dried as before. The yield was $2 \mathrm{mg}$. (second crop).

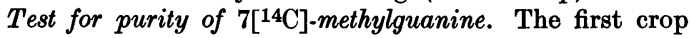
was used for this and subsequent experiments. The product was dissolved in $15 \mathrm{ml}$. of water, and a $0.5 \mathrm{ml}$. sample was made to $3-4 \mathrm{ml}$. with $1 \mathrm{~N}-\mathrm{HCl}$ containing carrier 7-methylguanine $(0.80 \mathrm{mg}$.) and guanine $(1.07 \mathrm{mg}$.) and analysed on a Dowex 50 column as described above. The major peak of radioactivity was pooled, evaporated to dryness and rechromatographed as described above. Though most of the radioactivity followed the $E_{260}$ profile of carrier 7-methylguanine, there were two minor peaks of radioactivity that were eluted from the column in the first few tubes. These amounted to $0 \cdot 19 \%$ and $0.09 \%$ of the total radioactivity. When the major peak of radioactivity was evaporated to dryness and rechromatographed, a similar pattern was obtained again. It is therefore probable that a small amount of decomposition of 7-methylguanine occurs during the drying and the chromatographic procedure. Possibly one of the peaks is due to the product of deamination, i.e. 7-methylxanthine.

Animals. Wistar albino rats of the Porton strain were maintained on M.R.C. diet 41B (Bruce \& Parkes, 1956). Female rats, $200 \mathrm{~g}$. body wt., were used except where otherwise stated.

Test for toxicity of 7-methylguanine. A total of $5 \cdot 12 \mathrm{mg}$. dissolved in $0.9 \% \mathrm{NaCl}$ was administered by repeated intraperitoneal injection over a period of 16 days.

Experiment on excretory products of $7\left[{ }^{14} \mathrm{C}\right]$-methylguanine. One rat was given an intraperitoneal injection of $10.95 \mu \mathrm{C}$ $\left(58.75 \mu \mathrm{g}\right.$.) of $7\left[{ }^{14} \mathrm{C}\right]$-methylguanine in $0.9 \% \mathrm{NaCl}$ and was placed in a metabolism unit for the collection of urine, faeces and expired $\mathrm{CO}_{2}$. Urine was frozen as excreted and was collected daily for 30 days. The $24 \mathrm{hr}$. samples were diluted to a convenient volume, and $0.1 \mathrm{ml}$. and $0.2 \mathrm{ml}$. portions were taken for determination of total radioactivity with dioxan scintillator. The purine fraction of urine was prepared by the method of Jackson \& Entenman (1957), as modified by Craddock \& Magee (1967), and was analysed by chromatography on a Dowex 50 (X12) column (1 cm. $\times$ $10 \mathrm{~cm}$.) with $1 \mathrm{~N}-\mathrm{HCl}$ and then a linear gradient to $4 \mathrm{~N}-\mathrm{HCl}$. The $E_{260}$ was determined on each fraction of the effluent, and radioactivity was determined after evaporation to dryness as described by Craddock \& Magee (1967).

The expired $\mathrm{CO}_{2}$ was collected in $3 \mathrm{~N}-\mathrm{NaOH}$ for $7 \mathrm{hr}$. and samples were taken at intervals. The carbonate was precipitated with $\mathrm{Ba}(\mathrm{OH})_{2}$, and its radioactivity was determined after suspension in a scintillator solution containing the thixotropic gel Cab-O-Sil.

Tests for incorporation of $7\left[{ }^{14} \mathrm{C}\right]$-methylguanine into nucleic acids. (1) In the adult rat. One rat was starved overnight and during the course of the experiment. The animal was given a series of five intraperitoneal injections of $21.9 \mu \mathrm{c}$ $\left(117.5 \mu \mathrm{g}\right.$.) of $7\left[{ }^{14} \mathrm{C}\right]$-methylguanine in $1 \mathrm{ml}$. of $0.9 \% \mathrm{NaCl}$. The injections were made at hourly intervals, and the animal was killed $1 \mathrm{hr}$. after the final injection. Nucleic acids were prepared from liver and small intestine by a modification of the method of Kirby (1962) as described by Craddock, Villa-Treviño \& Magee $(1968 b)$. The liver RNA and intestine DNA were hydrolysed in $1 \mathrm{~N}-\mathrm{HCl}$ at $100^{\circ}$ for $1 \mathrm{hr}$. and were analysed by column chromatography on a Dowex 50 (X12) column $(0.5 \mathrm{~cm} . \times 10 \mathrm{~cm}$.) with $1 \mathrm{~N}-\mathrm{HCl}$ and then an exponential gradient to $3 \mathrm{~N}-\mathrm{HCl}$.

(2) In the foetus and in the pregnant rat. Four pregnant rats were given $7\left[{ }^{14} \mathrm{C}\right]$-methylguanine by stomach tube, each being given $5 \mu \mathrm{C}(29 \mu \mathrm{g}$.) on the thirteenth, sixteenth and seventeenth days of pregnancy, and $2 \mu \mathrm{c}(12 \mu \mathrm{g}$.) on the eighteenth and nineteenth days. The animals were killed on the twentieth day of pregnancy, and the foetuses and maternal livers and small intestines were removed. Nucleic acids were isolated and analysed as described for the experiment on the adult rat.

Study of distribution of $7\left[{ }^{14} \mathrm{C}\right]-$ methylguanine in the pregnant rat, and of its conversion into nucleosides and nucleotides. A pregnant rat was given $7\left[{ }^{14} \mathrm{C}\right]$-methylguanine $(20 \mu \mathrm{c}, 117 \mu \mathrm{g}$.$) by stomach tube on the nineteenth day of$ pregnancy, and faeces and urine were collected separately for $2 \mathrm{hr}$. The animal was then killed by a blow on the head, and the major part of the liver was removed and placed, in liquid $\mathrm{N}_{2}$ within 30 sec. The remainder of the liver and the kidneys, lungs, stomach, stomach contents, small intestine, placentae and foetuses (after rinsing in water) were placed in liquid $\mathrm{N}_{2}$. The tissue and faeces were homogenized in $6 \%$ (w/v) $\mathrm{HClO}_{4}(20 \mathrm{ml}$, exception for small intestine, when $40 \mathrm{ml}$. was used), and after centrifuging samples (1 ml.) of supernatant were taken for radioactive assay with dioxan2,5-diphenyloxazole scintillator.

To test for the formation of nucleotides or nucleosides in liver, all operations were performed at $0-2^{\circ}$. The major part of the liver (9.05g.), removed from the animal as described above, was homogenized in ice-cold $6 \%(w / v)$ $\mathrm{HClO}_{4}$ and the homogenate kept in ice for $30 \mathrm{~min}$. After centrifuging, ice-cold $10 \%$ (w/v) $\mathrm{KOH}$ was added dropwise to the supernatant until the $\mathrm{pH}$ was 6-7 and, after standing for $30 \mathrm{~min}$. to allow precipitation of $\mathrm{KClO}_{4}$, the mixture was centrifuged. To the supernatant was added $1 \mathrm{~N}: \mathrm{HCl}$ to $\mathrm{pH} 3.5$, carrier guanine $(0.5 \mathrm{mg}$.) and adenine $(0.5 \mathrm{mg}$.$) , and$ the mixture was run on a Dowex 50 column $(1 \mathrm{~cm} . \times 10 \mathrm{~cm}$.) with water for the first $450 \mathrm{ml}$. followed by a $1-3 \mathrm{~N}-\mathrm{HCl}$ exponential gradient; the flow rate was $12.5 \mathrm{ml} . / \mathrm{hr}$. The $E_{260}$ and ultraviolet spectra were determined on fractions of the effluent.

The samples of peaks 1, 2 and 3 (Fig. 1) were pooled separately, evaporated to dryness and hydrolysed in $4 \mathrm{ml}$. of $1 \mathrm{~N}-\mathrm{HCl}$ at $100^{\circ}$ for $1 \mathrm{hr}$., and samples $(0.2 \mathrm{ml}$.) were taken for radioactivity determinations. Peak 1 was reanalysed on a Dowex 50 column $(0.5 \mathrm{~cm} . \times 9 \mathrm{~cm}$.) with a $1-3 \mathrm{~N}-\mathrm{HCl}$ exponential gradient; the flow rate was $25 \mathrm{ml} . / \mathrm{hr}$. The $E_{260}$ and radioactivity of the samples of effluent were determined. Peaks 2 and 3 were pooled and examined in the same way as peak 1 .

Fractions of effluent collected after the first $450 \mathrm{ml}$. were evaporated to dryness and radioactivity was determined with a toluene-2,5-diphenyloxazole scintillator solution. 


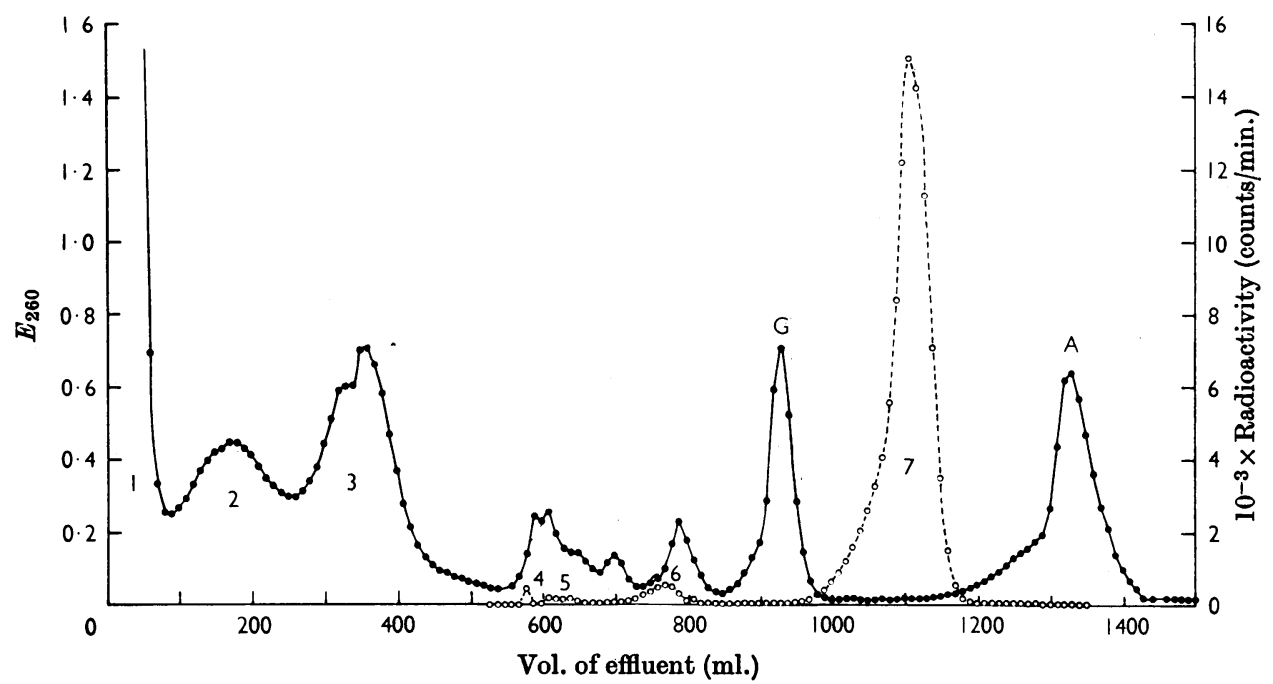

Fig. 1. Column chromatography of acid-soluble fraction of liver of rat after administration of $7\left[{ }^{14} \mathrm{C}\right]-\mathrm{methyl}-$ guanine, carrier guanine (G) and adenine (A) added. The Dowex 50 (X12) column $(1 \mathrm{~cm} . \times 10 \mathrm{~cm}$.) was eluted with water to $450 \mathrm{ml}$., then with a 1-3 $\mathrm{N}-\mathrm{HCl}$ exponential gradient. The numbers refer to the peaks of radioactivity. Total radioactivity of peak 1 was 770 counts/min., that of peak 2170 counts/min. and that of peak 3150 counts/ min. -0, $E_{260} ; 0--0$, radioactivity.

\section{RESULTS AND DISCUSSION}

The toxicity test did not reveal any toxic effects of 7-methylguanine at the dose used.

In the experiment studying the excretory products of $7\left[{ }^{14} \mathrm{C}\right]$-methylguanine, the excretion of ${ }^{14} \mathrm{C}$ in the expired air occurred linearly for the first $4 \mathrm{hr}$. after the injection, and then fell off rapidly. The total excretion amounted to approx. $0.9 \%$ of the dose of radioactivity. Most of the ${ }^{14} \mathrm{C}$ administered appeared in the urine during the $24 \mathrm{hr}$. after the injection, the excretion amounting to $93 \%$ of the dose. However, excretion of ${ }^{14} \mathrm{C}$ continued for a surprisingly long time, during the second day $(0.8 \%)$, third day $(0.4 \%)$ and fourth day $(0.2 \%)$, and the urine was still radioactive 30 days after the injection. Column chromatography of the purine fraction of the urine showed that nearly all the radioactivity was present in 7-methylguanine, even in the urine collected on the twentysixth to twentyninth days after injection. Two minor peaks of radioactivity, equivalent to $0.6 \%$ and $1.3 \%$ of the total radioactivity in the purine fraction, were similar to those found during chromatographic purification of $7\left[{ }^{14} \mathrm{C}\right]$-methylguanine, and also during chromatography of urine after addition of $7\left[{ }^{14} \mathrm{C}\right]$-methylguanine, and may therefore have been formed by the action of acid and Dowex 50 during the experimental procedure.

The liver RNA isolated from the rat given a total of $109.5 \mu \mathrm{C}$ of $7\left[{ }^{14} \mathrm{C}\right]$-methylguanine had a low content of radioactivity (110disintegrations/min./ mg.). Column chromatography showed that the ${ }^{14} \mathrm{C}$ was almost all in guanine and adenine, with no appreciable amount in 7-methylguanine. Thus a small amount of $\mathrm{N}$-demethylation of the $7\left[{ }^{14} \mathrm{C}\right]$ methylguanine may have occurred, the $\mathrm{C}_{1}$ compound formed being incorporated into guanine and adenine during biosynthesis. No more than a minute amount of 7-methylguanine could have been incorporated unchanged into RNA, though it is known to be a normal component of rat liver RNA (Craddock et al. 1968b).

To study possible incorporation of 7-methylguanine into DNA, a system was used in which frequent cell division and therefore DNA synthesis was taking place, i.e. small intestine. The DNA isolated had a low content of radioactivity (44 disintegrations/min./mg.), but chromatographic analysis showed all the ${ }^{14} \mathrm{C}$ to be in guanine, adenine and thymidylic acid, and no incorporation of 7-methylguanine as such was detected. Similarly, no evidence was found for incorporation of the base into foetal DNA or maternal liver RNA after repeated administration to the pregnant animal.

The results of the experiment on the distribution of $7\left[{ }^{14} \mathrm{C}\right]$-methylguanine after administration to a pregnant animal by stomach tube are shown in Table 1. By $2 \mathrm{hr}$. after treatment, a considerable proportion of the dose had passed into the urine, and the stomach contents, stomach and small intestine had higher-than-average radioactivity. 
Table 1. Distribution of radioactivity after administration of $7\left[{ }^{14} \mathrm{C}\right]$-methylguanine

$7\left[{ }^{14} \mathrm{C}\right]$-Methylguanine $(20 \mu \mathrm{c}, 117 \mu \mathrm{g}$.) was administered to a pregnant rat by stomach tube and the animal was killed after $2 \mathrm{hr}$.

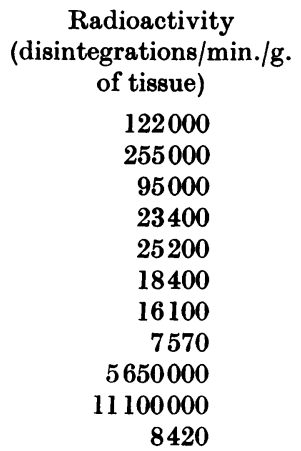

The ${ }^{14} \mathrm{C}$ was also concentrated to a certain extent in the kidney, but otherwise the distribution, expressed as disintegrations/min./g. of tissue, was uniform in the tissues studied, except for a smaller content in the placentae and foetuses. However, the slow passage across the placentae should not have invalidated the experiment testing incorporation of the base into foetal nucleic acids, where administration of the $7\left[{ }^{14} \mathrm{C}\right]$-methylguanine was repeated at daily intervals.

The chromatographic analysis of the acid-soluble fraction of liver is shown in Fig. 1. Most of the ${ }^{14} \mathrm{C}$ was found in the single peak 7 , eluted in the position of 7-methylguanine. After hydrolysis and rechromatography, peak 1 and pooled peaks $2+3$ gave a peak of $7\left[{ }^{14} \mathrm{C}\right]$-methylguanine, showing that some of the ${ }^{14} \mathrm{C}$ in peak 1 and peaks $2+3$ was due to nucleosides or nucleotides of 7-methylguanine. This amounted to $0.06 \%$ of the total radioactivity in the acid-soluble fraction in peak 1 and to $0.05 \%$ in peaks $2+3$. The nature of the radioactivity in peaks 4,5 and 6 is unknown, but could be 7-methylxanthine, formed by deamination of 7-methylguanine, or xanthine, hypoxanthine or amino acids, formed by metabolism of the $\mathrm{C}_{1}$ compound derived from the small amount of $N$-demethylation of $7\left[{ }^{14} \mathrm{C}\right]$-methylguanine. They amounted to $0.46 \%$, $0.93 \%$ and $3.35 \%$ respectively of the radioactivity in the 7-methylguanine peak.

Thus when $7\left[{ }^{14} \mathrm{C}\right]$-methylguanine is administered most is excreted unchanged in the urine, though a small amount of breakdown takes place, the resulting $\mathrm{C}_{1}$ compound being expired as carbon dioxide and also entering normal metabolic path- ways, including incorporation into purines during their biosynthesis. There is very little conversion of the intact base into nucleosides or nucleotides, and no detectable incorporation into RNA or DNA. Therefore where 7-methylguanine is found in normal nucleic acids its formation is due entirely to methylation of the nucleic acid at the polymer stage, as had been shown to occur with $\left[{ }^{14} \mathrm{C}\right]$ methionine as a methyl donor (Mandel \& Borek, 1963), and none is due to incorporation of the methylated base. Where an increased amount of 7-methylguanine has been found in nucleic acid after treatment with certain carcinogens, the methylated base must have been formed by local methylation of the nucleic acid, and not by incorporation of 7-methylguanine derived from another tissue. This concept is consistent with the hypothesis that methylation of nucleic acids by dimethylnitrosamine occurs only in those tissues in which the carcinogen is metabolized (Lee, Lijinsky \& Magee, 1964). Thus the base present after dimethylnitrosamine treatment must be in an abnormal sequence in the nucleic acid, and may conceivably be the cause of disturbed biological function.

The authors thank Mr J. A. E. Jarvis, Mr R. Hunt and Mr B. A. J. Alexander for skilled technical assistance.

\section{REFERENCES}

Bruce, H. M. \& Parkes, A. S. (1956). J. Anim. Tech. Ass. 7, 54.

Craddock, V. M. \& Magee, P. N. (1967). Biochem. J. 104, 435.

Craddock, V. M., Magee, P. N. \& Mattocks, A. R. (1968a). Biochem. J. 106, 9 P.

Craddock, V. M., Villa-Treviño, S. \& Magee, P. N. (1968b). Biochem. J. 107, 179.

Dunn, D. B. (1963). Biochem. J. 86, 14 P.

Gold, M., Hurwitz, J. \& Anders, M. (1963). Biochem. biophys. Res. Commun. 11, 107.

Jackson, K. \& Entenman, C. (1957). Amer. J. Physiol. 189, 315.

Jones, J. W. \& Robins, R. K. (1963). J. Amer. chem. Soc. 85, 193.

Kirby, K. S. (1962). Biochim. biophys. Acta, 55, 545.

Krüger, M. \& Salomon, G. Z. (1898a). Hoppe-Seyl. Z. 24, 364.

Krüger, M. \& Salomon, G. Z. (1898b). Hoppe-Seyl. Z. 26, 350.

Lee, K. Y., Lijinsky, W. \& Magee, P. N. (1964). J. nat. Cancer Inst. 32, 65.

Magee, P. N. \& Farber, E. (1962). Biochem. J. 83, 114.

Mandel, L. \& Borek, E. (1963). Biochemistry, 2, 555.

Novogrodsky, A., Gefter, M., Maitra, U., Gold, M. \& Hurwitz, J. (1966). J. biol. Chem. 241, 1977.

Remy, C. (1967). Biochim. biophys. Acta, 138, 253. 